\title{
THE IMPACT OF ENSO IN THE ATACAMA DESERT AND AUSTRALIAN ARID ZONE: EXPLORATORY TIME-SERIES ANALYSIS OF ARCHAEOLOGICAL RECORDS ${ }^{1}$
}

\author{
EL IMPACTO DE ENSO EN EL DESIERTO DE ATACAMA Y \\ LA ZONA ÁRIDA DE AUSTRALIA: ANÁLISIS EXPLORATORIOS \\ DE SERIES TEMPORALES ARQUEOLÓGICAS
}

\author{
Alan Williams², Calogero M. Santoro ${ }^{3}$, Michael A. Smith ${ }^{4}$, and Claudio Latorre ${ }^{5}$
}

\begin{abstract}
A comparison of archaeological data in the Atacama Desert and Australian arid zone shows the impact of the El Niño-Southern Oscillation (ENSO) over the last 5,000 years. Using a dataset of $>1400$ radiocarbon dates from archaeological sites across the two regions as a proxy for population change, we develop radiocarbon density plots, which are then used to explore the responses of these prehistoric populations to ENSO climatic variability. Under an ENSO regime, precipitation is in anti-phase between Australia and coastal Chile. As ENSO also impacts marine resource productivity in Chile and advection of moisture from the Amazon Basin, the net effects of ENSO on subsistence economies on either side of the Tropical Pacific should be positively correlated. This is confirmed by cross-spectral analysis of the radiocarbon density plots, which shows that population responses on either side of the Tropical Pacific are synchronous $(\mathrm{r}=>0.82)$. Both the Australian and Atacama desert records show a general increase in population from about $13 \mathrm{cal}$ kyr BP, increasing through the mid-Holocene climatic optimum. Following the intensification of ENSO around $3.7 \mathrm{cal} \mathrm{kyr} \mathrm{BP,} \mathrm{we} \mathrm{can} \mathrm{correlate} \mathrm{'boom} \mathrm{and} \mathrm{bust'} \mathrm{cycles} \mathrm{of} \mathrm{occupation} \mathrm{on} \mathrm{both} \mathrm{sides} \mathrm{of} \mathrm{the} \mathrm{Pacific,} \mathrm{including} \mathrm{the}$ collapse of the Atacama desert coastal economy and cultural system at $3 \mathrm{cal} \mathrm{kyr}$ BP and the decline of both the Atacama highlands and Central Australian dryland populations between 3-2 cal kyr BP. After 2 cal kyr BP adaptive responses to ENSO varied between these regions, though all dryland populations show resurgence in occupation.
\end{abstract}

Key words: Atacama Desert, Australian arid zone, population history, post-glacial time-series analysis, radiocarbon probability plots, ENSO variability, human-environmental interactions.

La comparación de datos arqueológicos del desierto de Atacama y de la zona árida de Australia muestra el impacto de El NiñoOscilación del Sur en los últimos 5.000 años. Con base en un listado de $>1.400$ dataciones radiocarbónicas de ambas regiones, utilizadas como fuente indirecta de fluctuaciones de la población, se realizaron gráficos de densidad de las dataciones para explorar las respuestas de las poblaciones prehistóricas a las variaciones climáticas provocadas por ENSO. Bajo un régimen ENSO las precipitaciones se encuentran en antefase entre Australia y la costa del norte de Chile. Dado que ENSO impacta en la productividad de los recursos marinos y suprime el ingreso de humedad de la cuenca del Amazonas, su efecto en las economías de subsistencia de ambos lados del Pacífico Tropical debería correlacionarse positivamente. Esto se confirma a través de análisis cruzados de espectros de gráficos de densidad de radiocarbonos, lo que muestra fluctuaciones sincrónicas de la población en ambos lados del Pacífico Tropical ( $r=>0,82$ ). Las bases de datos de Australia y del desierto de Atacama muestran un aumento gradual de la población desde los 13 mil cal años a.p., y un incremento importante durante el óptimo climático del Holoceno medio. La intensificación de ENSO a partir de los 3,7 cal años a.p. se correlaciona con ciclos de florecimiento y declinación de la ocupación humana en ambos lados del Pacífico, incluyendo el colapso del sistema económico y cultural en la costa del desierto de Atacama alrededor de 3 mil años cal a.p. y la declinación de la población en las zonas interiores áridas del Atacama y del centro de Australia, entre 3-2 mil años cal a.p. Posterior a 2 mil años cal a.p. las respuestas adaptativas varían entre ambas regiones, aunque se produce una recuperación general de las poblaciones en sus zonas áridas interiores.

Palabras claves: desierto de Atacama, zona árida de Australia, historias de población, análisis de series temporales postglaciales, gráficos de probabilidad de radiocarbonos, variabilidad ENSO, interacción humana y medio ambiente.

Artículo seleccionado de las presentaciones al Second Southern Hemisphere Desert Conference (Arica, octubre 2005).

HLA-Envirosciences Pty Limited, Level 5, 828 Pacific Highway, Gordon NSW 2072. Current address: Fenner School of Environment and Society, Australian National University, Canberra ACT 0200, Australia. alanw@arksolutions.com.au

3 Instituto de Alta Investigación, Departamento de Antropología, Universidad de Tarapacá, and Centro de Investigaciones del Hombre en el Desierto, Arica, Chile. calogero_santoro@yahoo.com

4 Address for Correspondence: National Museum of Australia, GPO Box 1901, Canberra ACT 2601. m.smith@nma.gov.au. Tel 61-2-62085335 Fax 61-2-62085130.

5 CASEB/Departamento de Ecología, Pontificia Universidad Católica de Chile, Alameda 340, Casilla 114-D. Institute of Ecology \& Biodiversity, Casilla 653, Santiago, Chile. clatorre@bio.puc.cl 
The El Niño-Southern Oscillation (ENSO) is a major driver of climatic variability on both sides of the Pacific, linking the environmental histories of the Atacama Desert and Australian drylands. In this paper, we ask whether the impact of ENSO can be detected in archaeological records from these diverse regions. We use time-series analysis of radiocarbon data from archaeological sites in the Atacama Desert and in the Australian arid zone to reconstruct and compare the long-term population history of these regions. Changing frequencies of ${ }^{14} \mathrm{C}$ ages from archaeological sites serve as a rough proxy for the timing and direction of population change, as well as a broad indication of differences in relative intensity of human activity between regions.

It is important to move beyond regional analyses when looking at global climatic phenomena such as ENSO. This study is the first attempt to compare archaeological records of ENSO on both sides of the Walker Circulation (in which ENSO is embedded), and as such is explicitly exploratory and comparative in approach. In the Atacama Desert, the intensification of the current ENSO cycle is reflected in a major decline in the use of the desert coast after 3 cal kyr BP and greater use of the interior. In Australian drylands, there is a widespread population collapse around $3 \mathrm{cal}$ kyr BP that we attribute to the initial impact of the current pattern of ENSO. The correlation in the timing of abrupt archaeological shifts on both sides of the Pacific reinforces the interpretation that these changes reflect the zonal impact of ENSO-driven climate variability.

\section{The Walker Circulation and ENSO}

The Walker Circulation is a pattern of zonal airflow across the tropical south Pacific driven by differences in sea surface temperature (SST) between the west and east of this region (Sturman and Tapper 2006). High SST and rising air over Indonesia generate a high-level flow of air that subsides off the west coast of South America and returns as easterly surface winds. This zonal atmospheric thermal circulation cell is coupled to westward circulation of surface waters, promoting upwelling of nutrient-rich cold water off the coasts of Peru and Chile. A strong Walker Circulation promotes convective rainfall over northern and eastern Australia and suppresses it over the coastal regions of Peru and Chile, but the system is inherently unstable and contributes to climatic variability and extremes of flood and drought on both sides of the Pacific. The contrast between SSTs across the region (measured by the Southern Oscillation Index or SOI) determines the strength of the Walker Circulation. Fluctuations are known as the El Niño-Southern Oscillation (ENSO). El Niño was first described and recognized as a climatic anomaly in 1890 , by Federico Pezet a geographer in Peru, and it was already well known amongst Peruvian fishermen and sailors (Glantz 1996:3, 13; Frézier 1713). A strong +SOI (La Niña) is generally associated with heavy rainfall over Australia, dry conditions on the coast of Chile, and wet conditions in the altiplano. When the SOI is negative (an El Niño), the circulation weakens or reverses, suppressing the upwelling of cold waters off the coast of South America, and creating drought in Australia, warmer wetter conditions in coastal Peru and Chile, and dry conditions in the altiplano. Recent evidence suggests that the Interdecadal Pacific Oscillation (IPO) and Indian Ocean Dipole (IOD) modify the extent to which ENSO affects Australian rainfall (Verdon et al. 2006; Samuel et al. 2006) but there is currently little data on their interplay with palaeoENSO (D'Arrigo et al. 2005).

Although palaeo-climatic data suggest that ENSO was a feature of global climate during past warm periods, most studies indicate that the current cycle dates from about $5 \mathrm{cal}$ kyr BP and significantly intensified after 3.7-3.0 cal kyr BP (Andrus et al. 2002; Carré et al. 2005; Donders et al. 2007; Fontugne et al. 1999; Gagan et al. 2004; Keefer et al. 1998; Koutavas et al. 2002; Koutavas et al. 2006; Rein et al. 2005; Riedinger et al. 2002; Sandweiss et al. 1996; 2001; Shulmeister 1999). This is in line with predictions from climatic models (Clement et al. 1999). However, a few studies suggest an earlier onset at 7-6.5 cal kyr BP, using data from Laguna Pallcacocha in Ecuador (Moy et al. 2002; Rodbell et al. 1999) or from the Western Equatorial Pacific (Tudhope et al. 2001). While such an early date for the onset of ENSO is yet to be corroborated, these studies also show a switch to a more vigorous pattern of climatic variability after 5-3.0 cal kyr BP.

\section{Historical Impact of ENSO}

In northern Chile, historical El Niño events are recorded as having a major impact on coastal waters, causing the collapse of local fisheries, mass 
mortality of marine organisms and birds, red tide, torrential rainfall, erosion of coastal lowlands and widespread flooding (Quinn and Neal 1992). The major effects of ENSO are on the marine biomass along the coast. El Niño events disrupt the trophic structure of marine ecosystems (Glynn 1988); create a pulse of severe drought in the highlands; and extreme rain in coastal regions of Peru and northern Chile. Between 1819 and 1991 historical records show 32 episodes of rain in the normally dry Atacama Desert. Of these, 21 were linked to El Niño (Ortlieb 1995:535), though there is no direct relationship between the magnitude of rain events on the coast and the intensity of ENSO (Aceituno 1992; Caviedes and Waylen 1987; Hocquenghem and Ortlieb 1992; cf. Quinn et al. 1987).

In contrast, on the altiplano -SOI events are associated with dry years. An intensified subtropical jetstream blocks the advection of moisture from the Amazon Basin and Gran Chaco during El Niño events (Garreaud et al. 2003; Vuille et al. 2000). The intensity of coastal fog may also be related to ENSO variability (i.e. Cereceda et al. 2002; Fontugne et al. 1999; Larraín et al. 2002) but this seems to have been of marginal importance for prehistoric occupation on the coast of northern Chile (though see Fontugne et al. 1999 for a contrary view).

In Australian deserts and drylands, ethnographic hunter-gatherer populations were extremely susceptible to changes in the annual and inter-decadal variability in rainfall and the flow-on effects these have on plant and animal resources and on foraging range. Responses to historically-recorded droughts show a pattern of contraction to the better-watered ranges and river systems, and fragmentation of the population remaining in affected areas (Kimber 1990), while episodic extremes of high rainfall, lake full conditions or high river discharge allowed major aggregations of people for ceremonies, social exchange - and in some cases communal exploitation of ephemeral but abundant resources. Not all of these periods of 'boom and bust' are attributable to ENSO events, but sufficient evidence exists to indicate that historical ENSO had major consequences for Aboriginal populations in the interior of the continent. Table 1 summarises the net impact of ENSO on subsistence economies in the Atacama and Australian deserts.

\section{History of archaeological research and ENSO}

There have been several attempts in the Andes to correlate climatic data and cultural change, but it is only recently that the effects of ENSO have been explored (Kolata 1993; Kolata and Ortloff 1996; Lanning 1963, 1967; Sandweiss et al. 2001; Seltzer and Hastorf 1990; Shimada et al. 1991; Usselmann et al. 1999; van Buren 2001). On the central coast of Peru, in an early study, Parson (1970) linked the decline of vegetation dependent on coastal fog to El Niño. In southern Peru, Fontugne et al. (1999) showed that precipitation from winter fogs was enhanced when El Niño was weak and suggested a correlation with coastal occupation in the Quebrada de los Burros (Tacna). Sandweiss et al. (2001) suggested that the main development of monumental temples on the north coast of Peru corresponds to a period when El Niño events were

Table 1. The impact of ENSO fluctuations on subsistence economies in the Atacama and Australian Deserts.

Although climatic parameters (temperature and precipitation) are out-of-phase when comparing Australia and the Atacama coast, the net impact on resource productivity is broadly synchronous across these regions.

Impacto de las fluctuaciones ENSO en las economías de subsistencia de los desiertos de Atacama y Australia. Aunque los parámetros climáticos (temperatura y precipitación) están desplazados entre Australia y la costa del Atacama, el impacto neto en la productividad de los recursos es sincrónico en términos generales en ambas regiones.

\begin{tabular}{cccc}
\hline ENSO phase & $\begin{array}{c}\text { Australian } \\
\text { arid zone }\end{array}$ & Atacama coast & Interior \& Highland Atacama \\
\hline + SOI & + & + & + \\
(La Niña) & $\begin{array}{c}\text { improved water resources } \\
\text { and bush foods }\end{array}$ & high marine productivity & $\begin{array}{c}\text { Improved water resources } \\
\text { and pasture for camelids }\end{array}$ \\
- SOI & - & - & - \\
(El Niño) & decline in critical water & decline in critical marine \\
& resources and bush foods & resources & $\begin{array}{c}\text { decline in precipitation-dependent } \\
\text { watesources and in pasture } \\
\text { for game or livestock }\end{array}$ \\
\hline
\end{tabular}


less frequent, between 5.8 cal kyr BP and 3.2-2.8 cal kyr BP. However, the present study is the first to identify the coincidence in timing between the intensification of ENSO c. 3 cal kyr BP and abrupt changes in the archaeological record along the coast and interior of the Atacama Desert (Northern Chile) (Grosjean et al. 2005; Núñez et al. 2002; Standen 2003; Standen et al. 2004).

In Australia, the influence of ENSO on seasonal rainfall was not widely recognized until publication of an influential paper by McBride and Nicholls (1983), and it was some time before archaeologists incorporated ENSO into their thinking. Hiscock (1994) suggested that late Holocene changes towards microlithic tool-kits around 4-3 cal kyr BP reflected greater mobility, in part a response to the greater environmental variability at this time. Clarkson and Wallis (2003) attempted to test this idea in a regional study in the northern savannah, but results were inconclusive. In eastern Australia, Turney and Hobbs (2006) found that the onset of the current pattern of ENSO (4-3 cal kyr BP) correlated with major changes in population in inland Queensland. Similarly, Cosgrove et al. (2007) argued that ENSO and its effects on fire regimes and vegetation were important catalysts in allowing permanent Aboriginal occupation of tropical rainforests in northeastern Australia. The present study develops ideas and approaches in Smith et al. (2008). In that study, we (AW and MAS) used time-series analyses of radiocarbon data to identify the impact of ENSO in Australian drylands. Here, we set that work in broader context by comparing Australian and South American records.

\section{Regional Setting}

\section{The Atacama Desert}

The lower Atacama Desert forms a narrow coastal desert of $\sim 180,000 \mathrm{~km}^{2}$ (Figure 1), running from Arequipa in southern Peru $\left(16^{\circ} \mathrm{S}\right)$, to Copiapó in northern Chile $\left(27^{\circ} \mathrm{S}\right)$. From the Pacific Ocean, the land rises abruptly to the foot of the Andes, with local relief exceeding $6,000 \mathrm{~m}$. This strip of desert, in many places, less than $100 \mathrm{~km}$ wide, is dissected by numerous large canyons or smaller quebradas (ravines), which in turn contain a range of mesic habitats and oases fed by stream flow and groundwater recharge from precipitation on the western slopes of the Andes.

The cold, north-flowing Humboldt Current constrains inland (upslope) penetration of Pacific air moisture (Houston and Hartley 2003). The littoral zone is barren with no vegetation and, apart from the mouth of the quebradas, only brackish water (Núñez and Varela 1967). The coastal escarpment supports lomas vegetation (Tillandsia tragophoba, Griselinia carlomunozii, Astragalus neobarnebyanus) dependent on winter fog (Dillon and Hoffmann 1997). Above 2,900 masl, the slopes of the Andes support a sparse vegetation of shrubs and small herbs, including the Prepuna $(2,900-3,100 \mathrm{~m})$ and Puna $(3,100-3,900 \mathrm{~m})$ vegetation belts (for details see Latorre et al. 2005).

Rainfall on the hyper-arid coast of the Atacama Desert is typically sparse and patchy $(0.6 \mathrm{~mm} / \mathrm{yr}$ in

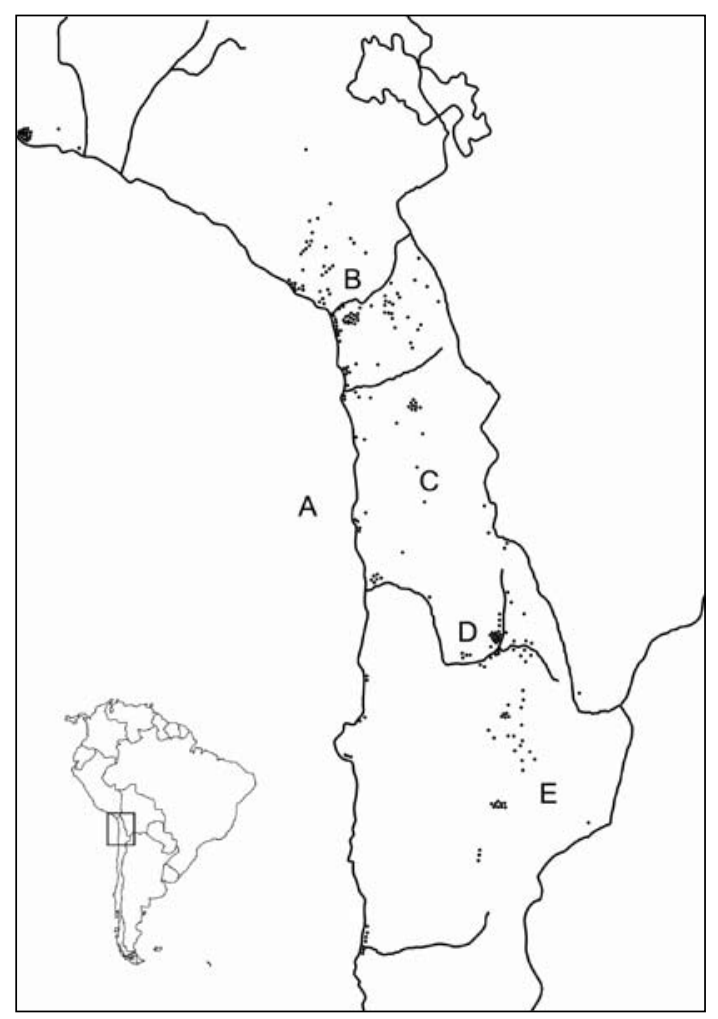

Figure 1. Distribution of archaeological sites $\left({ }^{14} \mathrm{C}\right.$-dated) in the Atacama Desert. (a) coastal strip; (b) oases and quebradas from Camaná to Camiña; (c) Pampa del Tamarugal basin; (d) Loa/ Calama basin; (e) Puna de Atacama ( $\mathrm{N}=295)$.

Distribución de los sitios arqueológicos (dataciones ${ }^{14} \mathrm{C}$ ) en el desierto de Atacama. (a) franja costera; (b) oasis y quebradas desde Camaná a Camiña; (c) Cuenca Pampa del Tamarugal; (d) Cuenca Loa/Calama; (e) Puna de Atacama (N=295). 
Arica) and up to 3,000 masl is strongly controlled by the effects of ENSO on local SST. In contrast, the interior of the Atacama receives much of its moisture from summer precipitation in the high Andes above $3,000 \mathrm{~m}$ (ranging from $40-350 \mathrm{~mm} / \mathrm{yr}$ ), which in turn is dependent on summer Amazon humidity in the Amazon Basin. El Niño (-SOI) events promote rainfall along the coast but suppress the inflow of moisture-bearing easterlies across the Andes, leading to a moisture deficit in the interior. La Niña (+SOI) events correspond to comparatively wet periods in the highlands (Ortlieb 1995; Usselmann et al. 1999). However, overall rainfall is very low irrespective of these small variations: With a UNEP aridity index $(\mathrm{P} /$ PET) of $<0.05$ the Atacama is uniformly hyper-arid (Middleton and Thomas 1997).

\section{The Australian arid zone}

The Australian arid zone is a continental mid latitude desert, covering 3-5 million $\mathrm{km}^{2}$ (approximately $70 \%$ of the continental land mass) depending on how its boundaries are determined (Figure 2). Within this large region, there are a wide variety of desert habitats (Mabbutt 1971), each with different potential for human occupation. These include arid littoral areas along the west coast and southern margin of the Nullarbor Plain, range and upland systems in the Pilbara and Central Australia, extensive areas of sandy desert or dune fields $\left(1.68\right.$ million $\left.\mathrm{km}^{2}\right)$ (Figure 3), and riverine tracts consisting of ephemeral or intermittent rivers and lakes, such as the Channel Country and Willandra Lakes system.

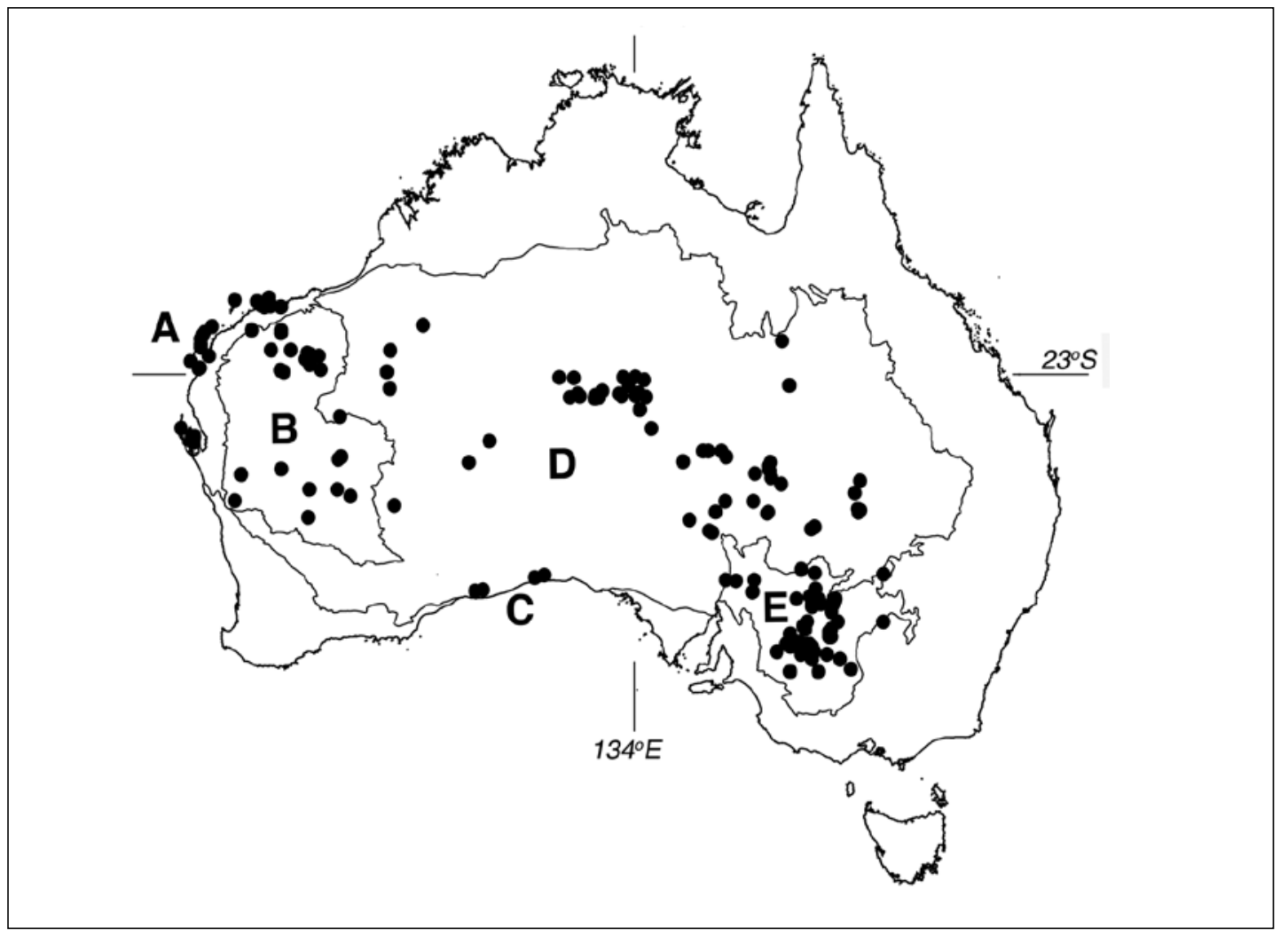

Figure 2. Distribution of archaeological sites $\left({ }^{14} \mathrm{C}\right.$-dated $)$ in Australian drylands $(\mathrm{N}=286)$. Outer boundary shows limits of Australian arid zone (after IBRA 6.1, Thackway and Cresswell 1995; and Gentilli 1972). (a) Arid west coast; (b) Pilbara and Murchison regions; (c) Nullarbor coast; (d) Arid interior, including sandy deserts and central Australian ranges; (e) Southeastern arid zone, including Murray-Darling Basin.

Distribución de los sitios arqueológicos (dataciones ${ }^{14} \mathrm{C}$ ) en las zonas desérticas de Australia (N=286). Los límites externos muestran la zona árida de Australia (de acuerdo a IBRA 6.1, Thackway y Cresswell 1995; y Gentilli 1972). (a) Costa oeste árida; (b) regiones de Pilbara y Murchison; (c) costa de Nullarbor; (d) Zona interior árida, incluye desiertos de dunas y la región de Australia central; (e) Zona árida sureste, incluye la cuenca Murray-Darling. 


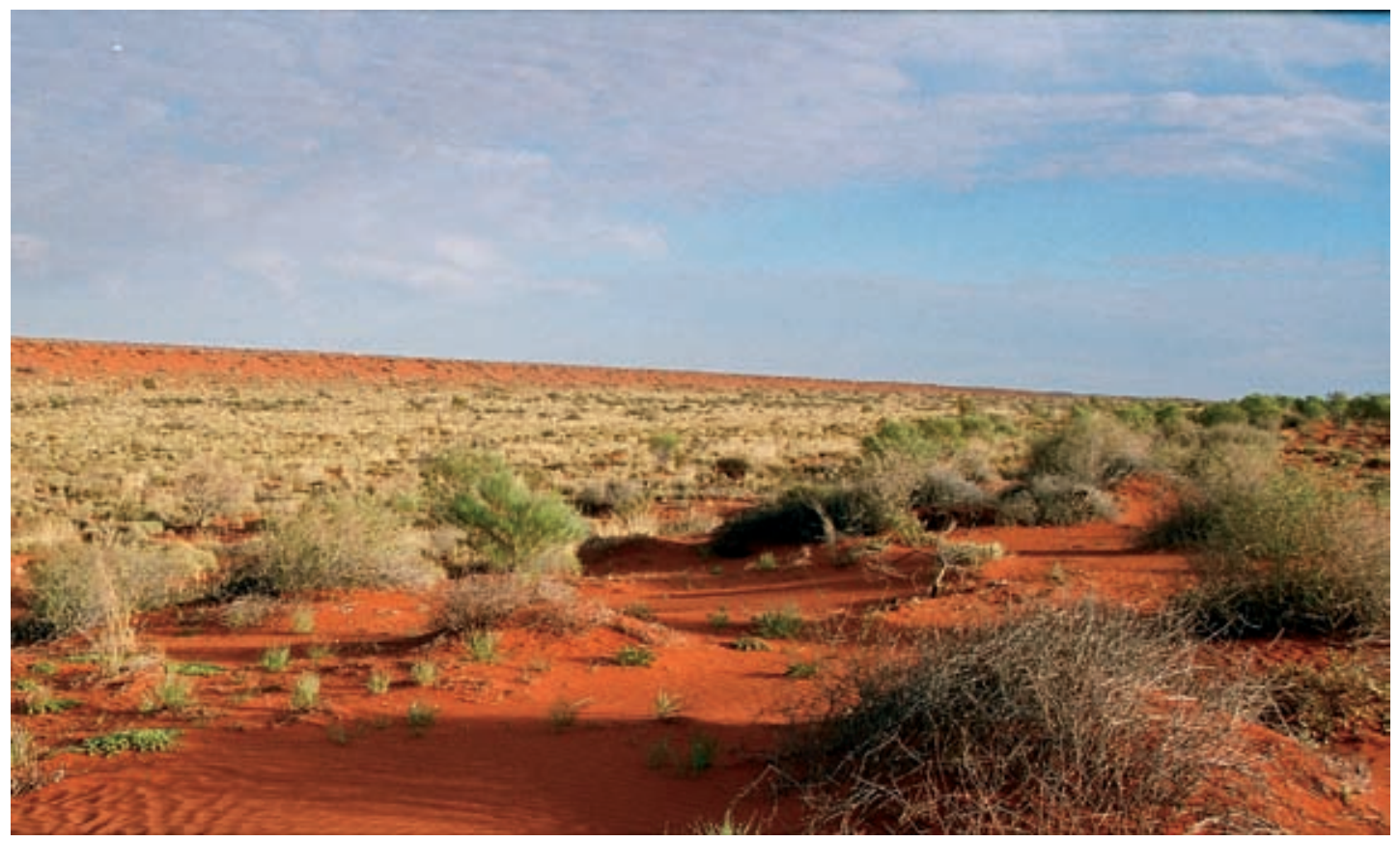

Figure 3. Sandy desert in the Australian arid zone, showing linear dunes with low shrubs and canegrass (Zygochloa) and dune corridors with Spinifex (Triodia). Photograph M.A. Smith (Simpson Desert, May 2006).

Desierto de dunas en la zona árida de Australia, con dunas lineales y vegetación de arbustos bajos y cañaverales (Zygochloa) y dunas en corredor con Spinifex (grama) (Triodia). Fotografía de M.A. Smith (desierto Simpson, mayo 2006).

Compared to the Atacama Desert, the Australian arid zone is well vegetated throughout, with Acacia and Eucalyptus species forming an open tree and shrub cover, hummock grasses (mainly Triodia and Plechtrachne) and chenopods (e.g. Atriplex) forming a perennial sp. understorey, with a flush of ephemeral or annual species (e.g. Asteraceae) after seasonal rain. Mean annual rainfall varies from $350-400 \mathrm{~mm}$ in the north to $250 \mathrm{~mm}$ in the south, but rates of evaporation are typically very high and for much of the region the UNEP aridity index (P/PET) falls between 0.05 and $<0.20$ (Middleton and Thomas 1997). The entire region has low relief $(<1500 \mathrm{~m}$ asl $)$ and local uplands rarely exceed $700 \mathrm{~m}$ above the surrounding plains. There are no oases or quebrada systems. Compared to the Atacama, water resources in the Australian desert are more widely distributed across the landscape, but are smaller, less reliable and have much lower rates of discharge. Variability in rainfall is also very high, compared to other desert regions: Alice Springs, in the centre of the region, has a median annual rainfall of $259 \mathrm{~mm}$ per annum, but received $903 \mathrm{~mm}$ in one year and only $54 \mathrm{~mm}$ in another year. A further point of contrast with the Atacama is that the west coast of Australia has a warm current, the Leeuwin Current, so is only moderately arid and lacks the rich fisheries that the cold Humboldt Current brings to the coast of Chile.

Rainfall in Australian drylands is influenced by several climate controls, all of which attenuate towards the centre of the continent (Gentilli 1972; Sturman and Tapper 2006): the Australian summer monsoon in the north; tropical cyclones in the Pilbara and adjacent coastal areas; ENSO variability in the Lake Eyre basin; and the winter Westerlies in the south. Spring and summer precipitation in the northern, central and eastern sectors of the arid zone is known to be positively correlated with the Southern Oscillation Index (Sturman and Tapper 2006: Fig. 11.28). The Walker circulation, in which ENSO is embedded, appears to have strengthened at about $5 \mathrm{cal}$ kyr BP (Shulmeister 1999). The initial effect in northern Australia was an enhancement of the monsoon, followed by an abrupt shift to a drier, more variable climate after $3.7 \mathrm{cal} \mathrm{kyr} \mathrm{BP}$. The number of ENSO events (in this context - major periods of below-average precipitation) appears to have 
sharply increased from about 4,000-3,000 years ago, peaked 1,500-1,200 years ago, then declined towards present (Moy et al. 2002; see also Rein et al. 2004) though some evidence indicates an increase in the frequency of extreme ENSO events during the last millennium (Riedinger et al. 2002: Fig. 3).

\section{Methods and Materials}

\section{Time-series analysis}

Time-series analysis, using ages-as-data, was pioneered by Rick (1987) in Peru. The method we use here treats radiocarbon density as a proxy for population history, on the premise that the number of radiocarbon ages is a measure of occupation intensity. In practice, a number of other factors also determine radiocarbon density distributions: the size of the dataset; the reduced visibility of older sites; the geomorphic history of sedimentary units; differential preservation of organics; and the selection of samples for radiometric dating (see Smith et al. 2008 for a review of methodology). The effects of these can be estimated and offset to some extent, but uncertainty must remain about the robustness of radiocarbon data as a proxy for trends in prehistoric population. Despite these problems, assembling sets of radiometric dates in this way has a long history in archaeology and is widely used as a first-order approximation of long-term prehistoric population trends (Barton et al. 2007; Gamble et al. 2004; 2005; Holdaway and Porch 1995; Lourandos 1993; Russell 2004; Shennan and Edinborough 2007; Turney and Hobbs 2006; Vermeersch 2005).

Time-series analysis also provides a formal statistical procedure for exploring quantitative records of variability in archaeological or environmental records (Weedon 2003). In this paper, we used the ARAND program (Howell 2001) to identify periodicities in the radiocarbon plots for each region. Spectral analysis allows detection of regular series cycles in a time-series, while crossspectral analysis allows correlation of spectra from two or more time-series.

\section{Archaeological records}

For the Atacama Desert, the available radiocarbon dataset consists of 861 ages from 295 archaeological sites (Figure 1). For analysis we have subdivided these into two groups:
- $\quad 331{ }^{14} \mathrm{C}$ dates from the coastal strip from $16^{\circ} \mathrm{S}$ to $25^{\circ} \mathrm{S}$, ranging from Quebrada Jaguay in southern Peru to Taltal in northern Chile;

- $\quad 530{ }^{14} \mathrm{C}$ dates from the interior and highland sectors of the Atacama Desert, including 289 samples for the northern Atacama highlands (including oases along the 12 quebradas from Camaná to Camiña) and 241 samples for the central Atacama (including the inland basins of Pampa del Tamarugal, Loa/Calama, and Puna de Atacama).

For the Australian arid zone, we use AustArch1, a database of radiocarbon determinations from archaeological sites in Australian drylands (Williams et al. 2007). This is currently the most comprehensive listing of radiocarbon ages for this region, listing 971 ages from 286 sites derived from published and unpublished research over the past 40 years. Figure 2 shows the distribution of dated sites. Our analysis focuses on three clusters of sites: those along the arid west coast of the continent, and those in the interior of the arid zone and in the PilbaraMurchison region ( $\mathrm{N}=570$ ages).

\section{Calibration and plotting}

Radiocarbon ages were calibrated with $\mathrm{OxCal}$ 4.03 (Bronk Ramsey 1995, 2001). For terrestrial samples, ages were calibrated with IntCal04 following a Southern Hemisphere correction of $40 \pm$ 13 years (Hogg et al. 2002). For marine samples, ages were calibrated using Marine04 with a local marine reservoir correction $(\Delta \mathrm{R})$ of $72 \pm 55$ years for Australia and $190 \pm 40$ for Chile (Reimer and Reimer 2001; Southon et al. 1995; Ulm 2006). Following the calibration of the dataset, OxCal was used to sum the probabilities (2-sigma level) to produce time-series graphs and outputs for subsequent statistical analysis.

\section{Results: The Archaeological Impact of ENSO}

Can we detect the impact of ENSO-driven climatic variability in these archaeological records? The historical dynamics of ENSO suggest that any increase in the frequency or strength of El Niño (-SOI) events will be marked by disruption of coastal ecosystems along the Atacama coast and suppression of rainfall in the interior of both the 
Australian and Chilean deserts. On this basis, we would expect the impact of ENSO on population levels to follow much the same trend on both sides of the Pacific, and that ENSO-driven archaeological events would be broadly synchronous across this region, at least with regards to the initial impact of the current ENSO cycle (Table 1).

This is in fact what we observe. ENSO appears to have intensified after $3.7 \mathrm{cal} \mathrm{kyr} \mathrm{BP} \mathrm{(Moy} \mathrm{et} \mathrm{al.}$ 2002; Shulmeister 1999) triggering increased variability in settlement on both sides of the Pacific (Figure 4). Its most direct ecological effect was the collapse of the fisheries along the Atacama coast by 3 cal kyr BP. This date appears to represent a critical tipping point for hunter-gatherer societies in the Australian arid zone and in the interior of the Atacama, as well as for specialized fishing communities along the Atacama coast (Figures 5 and 6). Cross-spectral analysis of detrended timeseries data over the last 13 cal kyr BP, comparing the Atacama (coast and interior) and the interior of the Australian arid zone (regions B \& D), gives a correlation of 0.7780 for the two series. If we restrict this analysis to the last $3 \mathrm{cal} \mathrm{kyr} \mathrm{BP}$ - to focus on the impact of ENSO - the correlation strengthens to 0.8386 . Alternatively, if we simply focus on the interior of these two deserts, comparing the Atacama interior with the interior of the Australian arid zone (regions B \& D) (over the last $13 \mathrm{cal} \mathrm{kyr}$ BP), cross-spectral analysis gives a correlation of 0.8293 on detrended data, compared to a correlation coefficient of $r=0.8859$ on unmodified ('trended') data. Collectively, these statistics confirm what we can see graphically in the time-series plots: The onset of ENSO-driven environmental variability has a marked and broadly synchronous impact on human societies on both sides of the South Pacific. Following the initial crash, adaptive and cultural responses to ENSO-driven variability necessarily varied across these regions (see below).

Figures 4-6 present time-series plots of archaeological radiocarbon data. These curves should be interpreted in broad terms, concentrating on major trends, peaks or troughs that reflect actual changes in population or level of human activity rather than the 'noise' generated by differences in sampling. As a proxy for changes in ENSO-driven climatic variability, we also plot the number of El Niño (-SOI) events /100yr from Moy et al. (2002). Although Moy et al. (2002) may exaggerate the extent of ENSO activity before 5 cal kyr BP (see above), their data represents the only long timeseries record available for cross-comparison with archaeological time-series data.

\section{The Atacama Desert}

Figure 4 shows the overall pattern for the Atacama. Population levels were relatively stable throughout the early Holocene, following initial colonisation of the region shortly before $13 \mathrm{cal}$ kyr BP. There was a stepwise increase between 6-5 cal kyr BP followed by a major population crash between 4-3 cal kyr BP. Population seems to have then rapidly recovered, peaking between 3-2 cal kyr

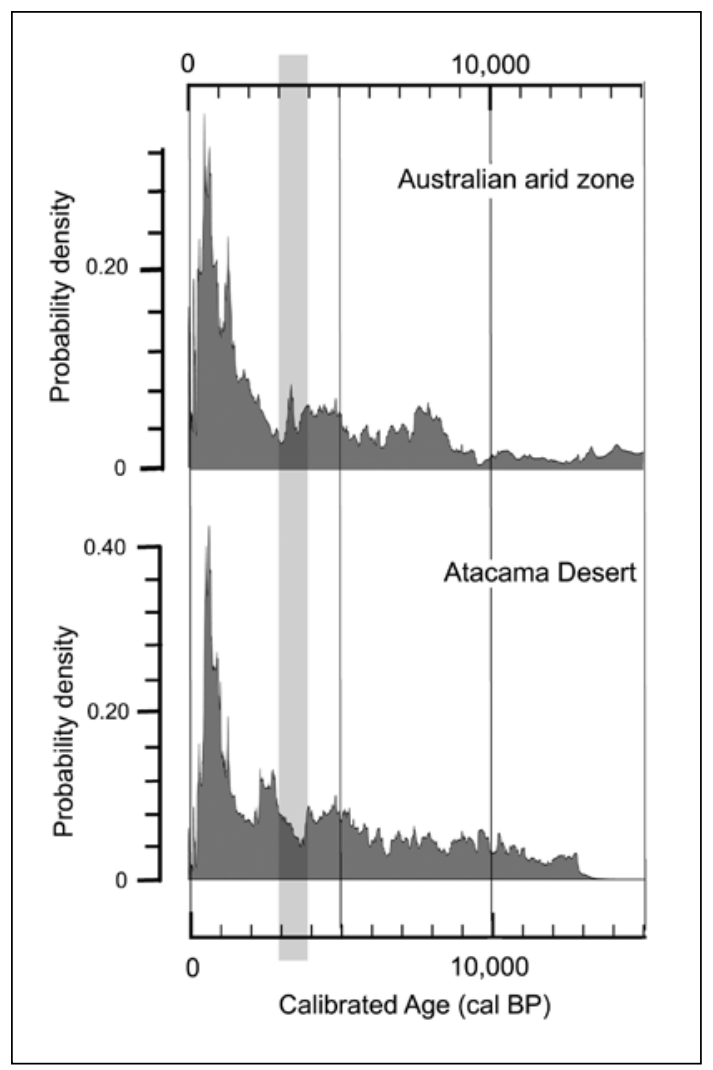

Figure 4. Summed probability plots for ${ }^{14} \mathrm{C}$ ages from archaeological sites in the Australian arid zone $(\mathrm{N}=908$. Note this excludes near-modern dates or dates with large errors, which are not readily calibrated) (top) and Atacama Desert, Chile (bottom) ( $\mathrm{N}=861$ ). Gray band marks the major onset of the current ENSO cycle at 4-3 cal kyr BP.

Gráfico de probabilidades de dataciones ${ }^{14} \mathrm{C}$ de sitios arqueológicos de la zona árida de Australia ( $N=908$. Note que se excluyeron las fechas más modernas o con grandes errores que no son fácilmente calibrados) (arriba) y del desierto de Atacama, Chile (abajo) (N=861). Las bandas grises marcan el comienzo de los ciclos más grandes de ENSO entre los 4-3 cal kyr a.p. 


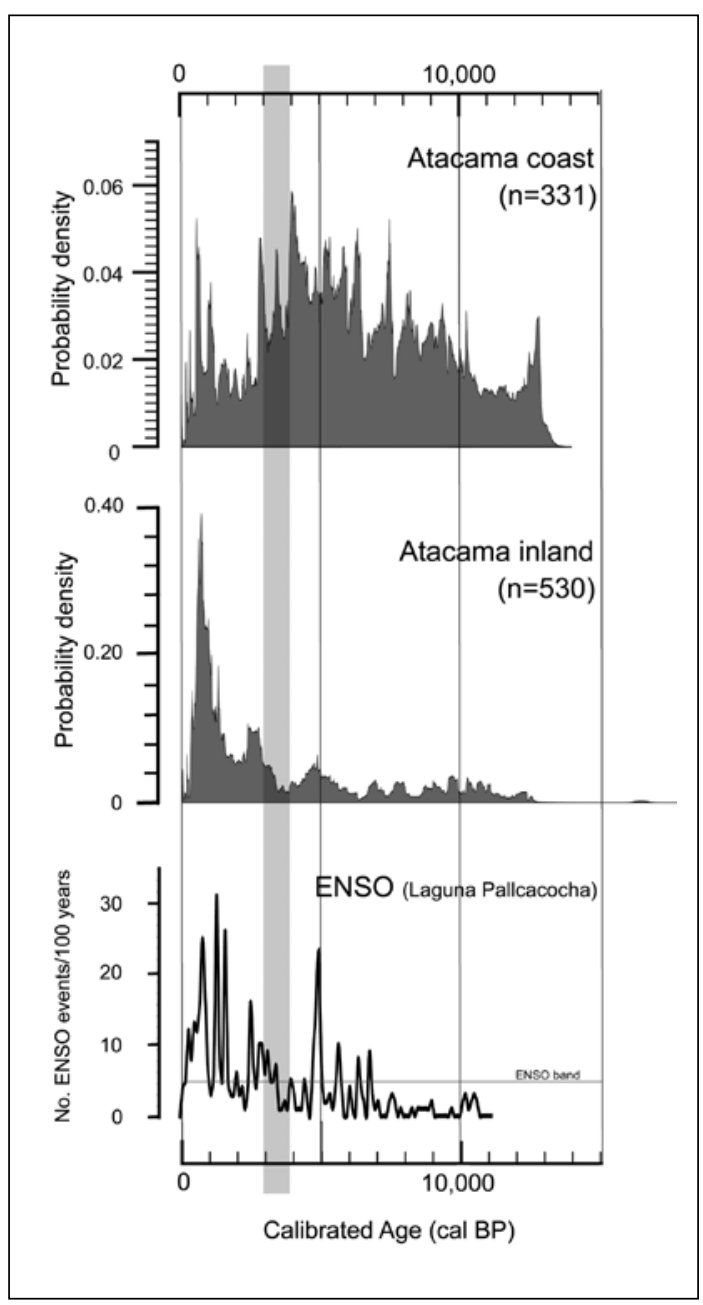

Figure 5. Summed probability plot for ${ }^{14} \mathrm{C}$ ages from archaeological sites in the Atacama Desert, comparing the coast and interior with variability in ENSO activity over the past 12,000 years (from Laguna Pallcacocha, Moy et al. 2002). Gray band marks the major onset of the current ENSO pattern at 4-3 cal kyr BP.

Gráfico de probabilidades de dataciones ${ }^{14} \mathrm{C}$ de sitios arqueológicos del desierto de Atacama, comparando la costa y el interior con variabilidad ENSO en los últimos 12.000 años (de Laguna Pallcacocha, Moy et al. 2002). La banda gris marca el comienzo de los ciclos más grandes de ENSO entre los 4-3 cal kyr a.p.

BP before sharply declining again. Figure 5 breaks these trends down to contrast the population history of coast and interior.

On the Atacama coast, there was a short pulse of activity associated with initial colonisation of the littoral shortly before 13 cal kyr BP (Figure 5), followed by consolidation of regional settlement at

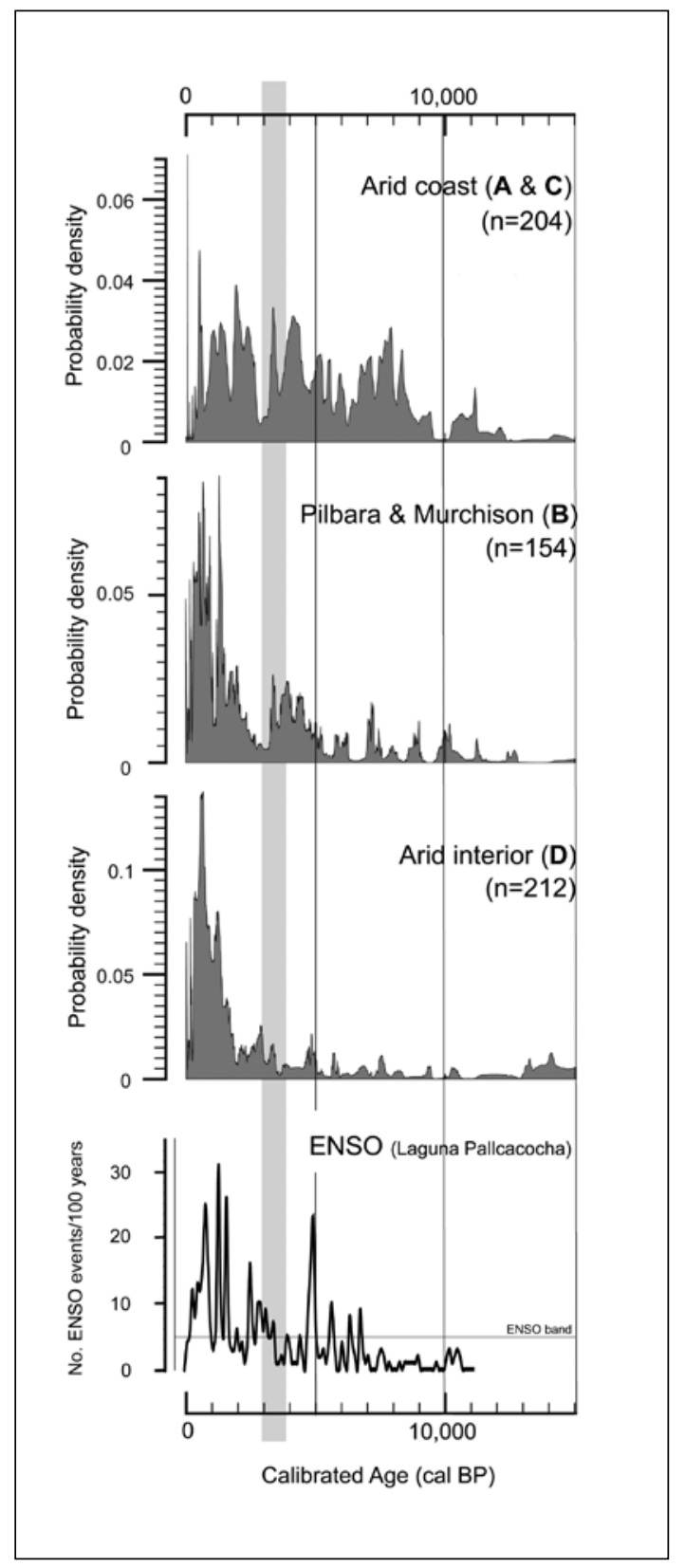

Figure 6. Summed probability plot for ${ }^{14} \mathrm{C}$ ages from archaeological sites in Australian drylands, broken down by region (see Figure 2 for locations), and compared with variability in ENSO activity over the past 12,000 years (from Laguna Pallcacocha, Moy et al. 2002). Gray band marks the major onset of the current ENSO pattern at 4-3 cal kyr BP.

Gráfico de probabilidades de dataciones ${ }^{14} \mathrm{C}$ de sitios arqueológicos de la zona árida de Australia por regiones (ver Figura 2 con ubicación de las distintas localidades) y comparada con la variabilidad de los eventos de ENSO en los últimos 12.000 años (de Laguna Pallcacocha, Moy et al. 2002). La banda gris marca el comienzo de los ciclos más grandes de ENSO entre los 4-3 cal kyr a.p. 
lower population levels. The process of colonization (Beaton 1991; Borrero and Franco 1997) was favoured by an increase in precipitation in the highlands that activated lowland drainage systems, and a marine environment dominated by nutrient-rich cold upwelling water (Baker et al. 2001; Carré et al. 2005; Keefer et al. 1998; Koutavas et al. 2002; Latorre et al. 2005; Moreno et al. 2007; Moy et al. 2002; Rodbell et al. 1999; Usselmann et al. 1999).

Once established, coastal populations grew strongly from $11 \mathrm{cal} \mathrm{kyr} \mathrm{BP.} \mathrm{Between} 11$ and $4 \mathrm{cal}$ kyr BP, Figure 5 shows a saw-toothed pattern of expansion and collapse, with oscillations around an overall trend towards increasing population. This period is also marked by a geographic expansion of settlement and increasing use of specialised marine technology. Both of these developments coincide with a decline in the intensity or frequency of ENSO events, especially after 9 cal kyr BP, and the productivity associated with upwelling coastal waters (Figure 5) (Carré et al. 2005; Keefer et al. 1998) and enhanced moisture from winter fogs (Fontugne et al. 1999). It appears that the Chinchorro culture in the northern Atacama (Arriaza 1995; Grosjean et al. 2007; Standen 1997, 2003; Standen and Arriaza 2000; Standen et al. 2004), enjoyed a particularly rich, stable and highly predictable marine environment.

Coastal settlement became markedly less stable after 4 cal kyr BP, with the onset of the current ENSO cycle, leading to a major collapse of the system at 2.5 cal kyr BP. Cross-correlation of time-series data supports this: For the period from 7-2 cal kyr $\mathrm{BP}$, population levels on the coast are inversely correlated with the number of ENSO events. The sharp decline evident in the time-series data also corresponds to an abrupt cultural change in excavated sites. Many coastal sites are abandoned. Others reflect an abrupt broadening of the economic base away from marine resources to include horticultural products -such as yam, manioc, chilli pepper, and corn- coupled with more extensive trade networks (Arriaza 1995; Grosjean et al. 2007; Núñez et al. 2008; Rivera 1991; Rothhammer et al. 2007; Standen et al. 2004). There is also a shift away from artificial mummification and collective burial, towards a pattern of individual funerary rituals. Coastal populations gradually recovered after $2.5 \mathrm{cal} \mathrm{kyr}$ $\mathrm{BP}$ but were reliant on a mixed agricultural/marine economy and did not reach the levels seen in the mid Holocene. The archaeological data indicate that the onset of the current ENSO cycle had two main effects on coastal populations: it caused the collapse of a distinctive specialised marine economy; and the increase in environmental variability was an important catalyst for broadening the economic base to include tropical agricultural crops and the strengthening of trade and political links with inland resource zones. The interior of the Atacama shows a complementary pattern of events, with a series of pulses of occupation reflecting discrete phases of cultural use of the interior.

Colonisation in the interior was more gradual than on the coast, beginning about $12.5 \mathrm{cal}$ kyr BP, when local precipitation increased on the slopes of the Andes. Population levels then oscillated around a comparatively low mean, with well-documented declines at 8.2 and $6.5 \mathrm{cal} \mathrm{kyr} \mathrm{BP.} \mathrm{The} \mathrm{last} \mathrm{of} \mathrm{these}$ is known to coincide with the beginning of drier and more variable environmental conditions in the interior. It also reflects an archaeological discontinuity in settlement in this region, with a shift towards a more dispersed population, more mobile huntergatherer groups, and to logistic stone tool kits. A second pulse of highland settlement, centred on 4.9 cal kyr BP, is characterized by low-density use of caves and open camps, focussed on ecological refuge areas.

The onset of ENSO is marked by a pulse of occupation between 3-2 cal kyr BP, offsetting the collapse of coastal settlement at this time. In the interior, this phase of occupation was marked by increasing reliance on a pastoral economy, with domestic camelids and a semi-sedentary pattern of settlement with fixed camps and basic stone architecture, and imported goods from the Pacific and the Atlantic coasts. This was a short-lived phase - lasting no more than $1000 \mathrm{yrs}$ - brought to an end by another sharp decline at 2 cal kyr BP. The steady population growth after $2 \mathrm{cal}$ kyr BP reflects the expansion of small-scale local polities (simple chiefdoms) linked to larger societal structures, such as the Tiwanaku state and the Inka Empire in the Andes (Berenguer 2000; Bruhns 1994).

\section{The Australian arid zone}

Our data suggests that Aboriginal settlement in the interior of the Australian arid zone (in particular in Central Australia and the Lake Eyre basin) was sensitive to ENSO-driven climatic variability. In support of this, cross-spectral analysis of radiocarbon 
density plots for the arid interior and the number of ENSO events/100 years (Moy et. al. 2002), over the last 13,000 years, shows that the two are positively correlated (0.4498). De-trended spectral analysis on archaeological data for the last $10 \mathrm{cal}$ kyr BP (combining all regions except the Murray-Darling Basin) also indicates periodicities of 1340 years and 175 years, suggesting that arid zone populations responded to millennial and sub-millennial climatic variability. The former is similar to the 1470-year periodicity reported for ENSO.

Figure 4 shows the summed probability plots for the entire AustArch1 dataset. Figure 6 breaks this down by region, concentrating on the past 15,000 years. Overall, there is a stepped pattern of population growth, with major steps at 8 and $1.5 \mathrm{cal}$ kyr BP, though these thresholds are not uniformly expressed across the arid zone (see Smith et al. 2008 for more details). Within this pattern, our time-series data show a distinct saw-toothed pattern of population expansion and collapse, with a sharp decline in population around $3 \mathrm{cal} \mathrm{kyr} \mathrm{BP}$ evident across all regions. This is a short, widespread collapse, about 500 years in duration, followed by a period of major population growth in the late Holocene.

Arid coastal regions show a sustained increase in site visibility from 8 cal kyr BP, as the last marine transgression created extensive and productive mangrove swamps (the 'Big Swamp' phase) across northern Australia (Mulrennan and Woodroffe 1998; Woodroffe et al. 1985). In the Murray-Darling Basin, there is a marked peak in site visibility at $8 \mathrm{cal} \mathrm{kyr}$ $\mathrm{BP}$ representing sites associated with major rivers, which experienced increased discharge around this time. Away from the coasts and rivers, this period may also have seen some increase in regional populations, but data is patchy at present.

Australian arid zone hunter-gatherer populations appear to have expanded during the early part of the current ENSO cycle (5-3 cal kyr BP), with a sharp population decline at $3 \mathrm{cal}$ kyr BP across the arid zone as a drier, more variable climate became established.

Populations along the arid west coast of the continent were also affected by the collapse at $3 \mathrm{cal} \mathrm{kyr}$ $\mathrm{BP}$, though in this case the use of marine resources appears to have buffered coastal populations from other environmental oscillations. Unlike the Atacama coast, the west coast of Australia did not have rich fisheries, nor specialised marine economies. Nor is it a region where ENSO is strongly correlated with marine productivity. In this region, site abandonment coincides with the decline of the mid Holocene mangrove swamps (Przywolnik 2005), as a result of silting and shoreline progradation. A connection with ENSO has not been shown, but increasing climatic variability would affect sediment loads driving such coastal morphodynamics.

The widespread collapse of inland desert populations around $3 \mathrm{cal} \mathrm{kyr} \mathrm{BP}$ appears to reflect the combined effects of weaker summer monsoon rainfall and the onset of the current cycle of ENSO activity. Some of the archaeological impacts have been explored by Hiscock (1994), but the effects on site use and patterns of subsistence and land use in the arid zone are yet to be explored in any detail. After 3 cal kyr BP most regions saw a rapid recovery, but in the arid interior - and in particular in Central Australia (see Smith and Ross 2008) this was delayed until 1.5 cal kyr BP.

In most regions, there is a significant increase in human activity from 1.5-1 cal kyr BP. The decline in ENSO activity from 1.2 cal kyr BP (or the shift to fewer but more extreme ENSO events) appears to underpin both an expansion of grassland in Central Australia and Aboriginal settlement (as Turney and Hobbs 2006, also found in inland Queensland). The disproportionate amplitude of the population response suggests that one of the effects of the peak in late Holocene ENSO activity was to breach a critical human-environment threshold, leading to an abrupt shift to a new pattern of land use. In Central Australia, much of the archaeological evidence points directly to regional population growth, beginning 1.5-1 cal kyr BP (see Smith and Ross 2008, for a detailed review). Hunter-gatherer groups appear to have increased their use of marginal or outlying areas, and extended their use of existing sites. Grindstones for processing Acacia and grass seeds became a more prominent part of site assemblages (Smith 1986, 2004). An increase in territoriality is reflected in the greater differentiation of rock art complexes after $1.5 \mathrm{cal}$ kyr BP.

\section{Conclusion}

This exploratory research emerged from the idea that ENSO is a global climatic phenomenon likely to affect desert societies on both sides of the Pacific. In fact, we argue that the effects of ENSO are best seen at a zonal rather than regional scale. In this paper we have compared time-series 
archaeological records from the Atacama Desert and the Australian arid zone, using radiocarbon densities as a proxy for human occupation. The intensification of ENSO after $3.7 \mathrm{cal} \mathrm{kyr} \mathrm{BP}$ appears to have triggered increased (and broadly synchronous) instability in settlement on both sides of the Pacific. The most direct ecological effect of ENSO was the decline of fisheries along the Atacama coast. The 3 cal kyr BP event appears to represent a critical tipping point for hunter-gatherer societies in the Australian arid zone and in the interior of the Atacama, as well as for specialized fishing communities along the Atacama coast. Following this crash, adaptive and cultural responses to ENSO varied across these regions, but we conclude that the onset of ENSO-driven environmental variability had a marked impact on human societies on both sides of the South Pacific.

We put this forward as a testable hypothesis requiring further corroboration against archaeological data. The population trends shown in our radiocarbon density plots need to be tested against multi-proxy records for relative population density in each region, and larger ${ }^{14} \mathrm{C}$ datasets (as these become available). Where ENSO is the cause of population changes, we expect broadly synchronous impacts on societies on either side of the Pacific (though the character of responses may differ) and we expect archaeological records to show shifts in those aspects of the palaeo-economy most likely to be affected by ENSO-driven climatic variability. The latter may include coastal resources (in the case of the eastern Pacific), productivity of wild plant foods or cultigens, water harvesting strategies and changes in group mobility.

Acknowledgements: This paper is a contribution to the IHOPE (Australia) program at the Fenner School of Environment and Society, Australian National University. We thank C. Turney, University of Exeter, for advice on methods. In Australia, C. Santoro was supported by a DEST Endeavour Research Fellowship (Australian Government) and by Visiting Fellowships at the National Museum of Australia and the Fenner School, ANU. We acknowledge other research support from the University of New England (Armidale NSW, Australia), the Center of Advanced Studies in Ecology and Biodiversity (CASEB) and Institute of Ecology and Biodiversity (P05-002 ICM), and the National Museum of Australia. CS and CL also acknowledge support from FONDECYT Grant 1070140 and a Grant of the Dirección de Investigaciones y Post Grado, Centro de Investigaciones del Hombre en el Desierto CIHDE, and the Instituto de Alta Investigación of Universidad de Tarapacá, Arica, Chile.

\section{References Cited}

Aceituno, P.

1992 El Niño, the Southern Oscillation, and ENSO: Confusing names for a complex ocean-atmosphere interaction. Bulletin of the American Meteorological Society 73:483-485.

Andrus, C.F.T., D.E. Crowe, D.H. Sandweiss, E.J. Reitz, and C.S. Romanek

2002 Otolith $\delta{ }^{18} \mathrm{O}$ record of Mid-Holocene Sea Surface Temperatures in Peru. Science 295:1508-1511.

Arriaza, B.T.

1995 Beyond Death: The Chinchorro Mummies of Ancient Chile. Smithsonian Institution Press, Washington.

Baker P.A., C.A. Rigsby, G.O. Seltzer, S.C. Fritz, T.K. Lowensteink, N.P. Bacher, and C. Véliz

2001Tropical climate changes at millennial and orbital timescales on the Bolivian Altiplano. Nature 409:698-701.

Barton, L., P.J. Brantingham, and J. Duxue

2007 Late Pleistocene climate change and palaeolithic cultural evolution in northern China: Implications from the last glacial maximum. In Late Quaternary Climate Change and Human Adaptation in Arid China, edited by D.B. Madsen, F.H. Chen, and X. Gao, pp. 105128. Developments in Quaternary Science 9, Elsevier, Amsterdam.
Beaton, J. M.

1991 The first Americans: Search and research. In The First Americans: Search and Research, edited by T.D. Dillehay and D.J. Meltzer, pp. 209-230. CRC, Boca Raton.

Berenguer, $\mathrm{J}$.

2000 Tiwanaku: Lords of the Sacred Lake. Museo Chileno de Arte Precolombino, Santiago.

Borrero, L., and N. Franco

1997 Early Patagonian hunter-gatherers: Subsistence and technology. Journal of Anthropological Research 53:219239.

Bronk Ramsey, C.

1995 Radiocarbon calibration and analysis of stratigraphy: The OxCal program. Radiocarbon 37:425-430.

2001 Development of the radiocarbon calibration program OxCal. Radiocarbon 43:355-363.

Bruhns, K.O.

1994 Ancient South America. Cambridge University Press, Cambridge.

Carré, M.I.B., M. Fontugne, and D. Lavallée

2005 Strong El Niño events during the early Holocene: Stable isotope evidence from Peruvian sea shells. The Holocene 15:42-47. 
Caviedes, C.N., and P.R. Waylen

1987 El Niño y crecidas anuales en los ríos del norte del Perú. Bulletin de l'Institut Français d'Études Andines 16:1-19.

Cereceda P., P. Osses, H. Larraín, M. Farías, M. Lagos, R. Pinto, and R.S. Schemenauer

2002 Advective, orographic and radiation fog in the Tarapacá region, Chile. Atmospheric Research 64:261-271.

Clarkson, C., and L.A. Wallis

2003 The search for El Niño/Southern Oscillation in archaeological sites: Recent phytolith analysis at Jugali-ya rock shelter, Wardaman Country, Australia. In Phytolith and Starch Research in the Australian-Pacific-Asian Regions: the State of the Art, edited by D.M. Hart, and L.A. Wallis, pp. 137152. Terra Australis 19, Pandanus Books, Canberra.

Clement, A.C., H. Seager, and M.A. Cane

1999 Orbital controls on the El Niño/Southern Oscillation and tropical climate. Palaeoceanography 14:441-456.

Cosgrove, R., J. Field, and A. Ferrier

2007 The archaeology of Australia's tropical rainforests. Palaeogeography, Palaeoclimatology, Palaeoecology 251:150-173.

D’Arrigo, R., E.R. Cook, R.J. Wilson, R. Allan, and M.E. Mann

2005 On the Variability of ENSO over the past Six Centuries. Geophysical Research Letters 32, L03711, doi: 10.1029/2004GL022055.

Dillon, M.O., and A.E. Hoffmann

1997 Lomas formations of the Atacama Desert, Northern Chile. In Centres of Plant Diversity, a Guide and Strategy for their Conservation, edited by S.D. Davis, V.H. Heywood, O. Herrera-McBryde, J. Villa-Lobos and A.C. Hamilton, pp. 528-535. WWF, Information Press, Oxford.

Donders, T. H., S.G. Haberle, G. Hope, F. Wagner, and H. Visscher

2007 Pollen evidence for the transition of the Eastern Australian climate system from the post-glacial to the present-day ENSO mode. Quaternary Science Reviews 26:1621-1637.

Fontugne, M., P. Usselmann, D. Lavallée, M. Julien, and C. Hatté

1999 El Niño variability in the coastal desert of southern Peru during the mid-Holocene. Quaternary Research 52:171179.

Frézier, A.F.

1713 A voyage to the South-Sea, and along the Coasts of Chili and Peru, in the years 1712, 1713, and 1714: particularly describing the...inhabitants, as well Indians as Spaniards. Jonah Bowyer, London.

Gagan, M.K., E.J. Hendy, S.G. Haberle, and W.S. Hantoro 2004 Post-glacial evolution of the Indo-Pacific Warm Pool and El Niño-Southern Oscillation. Quaternary International 118-119:127-143.

Gamble, C., W. Davies, P. Pettitt, and M. Richards 2004 Climate change and evolving human diversity in Europe during the last glacial. Philosophical Transactions of The Royal Society B 359:243-254.

Gamble, C., W. Davies, P. Pettitt, L. Hazelwood, and M. Richards

2005 The archaeological and genetic foundations of the European population during the late glacial: Implications for 'Agricultural Thinking'. Cambridge Archaeological Journal 15:193-223.
Garreaud, R., M. Vuille, and A.C. Clement

2003 The climate of the altiplano: observed current conditions and mechanisms of past changes. Palaeogeography, Palaeoclimatology, Palaeoecology 194:5-22.

Gentilli, J.

1972 Australian Climate Patterns. Thomas Nelson, Melbourne.

Glantz, M.H.

1996 Currents of Change: El Niño Impact on Climate and Society. Cambridge University Press, Cambridge.

Grosjean, M., L. Núñez, and I. Cartajena

2005 Cultural response to climate change in the Atacama Desert. In $23^{\circ}$ South: The Archaeology and Environmental History of the Southern Deserts, edited by M. Smith and P. Hesse, pp. 156-171. National Museum of Australia, Canberra.

Grosjean, M., C.M. Santoro, L.G. Thompson, L. Núñez, and V.G. Standen

2007 Mid-Holocene climate and cultural change in the SouthCentral Andes. In Climate Change and Cultural Dynamics a Global Perspective on Mid-Holocene Transitions, edited by D. Anderson, K. Maasch, D. Sandweiss, pp. 51-115. Academic Press, San Diego.

Glynn, P.W.

1988 El Niño-Southern Oscillation 1982-1983: Nearshore population, community, and ecosystem responses. Annual Review of Ecology and Systematics 19:309-345.

Hiscock, P.

1994 Technological responses to risk in Holocene Australia. Journal of World Prehistory 8:267-292.

Hocquenghem, A.M., and L. Ortlieb

1992 Eventos El Niño y lluvias anormales en la costa del Perú: siglos XVI-XIX. Bulletin de l'Institut Français d'Études Andines 21:197-278.

Hogg, A.G., F.G. McCormac, T.F.G. Higham, P.J. Reimer, M.G.L. Baillie, and J.G. Palmer

2002 High-precision radiocarbon measurements of contemporaneous tree-ring dated wood from the British Isles and New Zealand: AD 1850-950. Radiocarbon 44:633-640.

Holdaway, S., and N. Porch

1995 Cyclical patterns in the Pleistocene human occupation of Southwest Tasmania. Archaeology in Oceania 30:74-82.

Houston, J., and A.J. Hartley

2003 The Central Andean West-slope rainshadow and its potential contribution to the origin of hyper-aridity in the Atacama Desert. International Journal of Climatology 23:1453-1464.

Howell, P.

2001 ARAND time series and spectral analysis package for the Macintosh, Brown University. IGBP PAGES/World Data Center for Paleoclimatology, Data Contribution Series \#2001-031. NOAA/NGDC Paleoclimatology Program, Boulder, Colorado.

Keefer, D.K., S.D. deFrance, M. Moseley, J. Richardson III, D. Satterlee, and A. Day-Lewis

1998 Early maritime economy and El Niño events at Quebrada Tacahuay, Peru. Science 281:1833-1835.

Kimber, R.G.

1990 Hunter-gatherer demography: the recent past in Central Australia. In Hunter-Gatherer Demography: Past and Present, edited by B. Meehan, and N. White, pp. 160-170. Oceania Monograph 39, University of Sydney, Sydney. 
Kolata, A.L.

1993 The Tiwanaku: Portrait of an Andean Civilization. Blackwell, Cambridge.

Kolata, A.L., and C. Ortloff

1996 Agroecological perspectives and the decline of the Tiwanaku State. In Tiwanaku and its Hinterland, edited by A.L. Kolata, pp. 181-201. Smithsonian Institution Press, Washington DC.

Koutavas, A., J. Lynch-Stieglitz, T.M. Marchitto, and J.P. Sachs

2002 El Niño-like patterns in ice age tropical Pacific sea surface temperature. Science 297:226-230.

Koutavas, A., P.B. deMenocal, G.C. Olive, and J. LynchStieglitz

2006 Mid-Holocene El Niño- Southern Oscillation (ENSO) attenuation revealed by individual foraminifera in eastern tropical Pacific sediments. Geology 34:993-996.

Lanning, E.P.

1963 A Pre-Agricultural Occupation on the Central Coast of Peru. American Antiquity 28:360-371.

1967 Peru before the Incas. Prentice-Hall, New Jersey.

Larraín, H., F. Velásquez, P. Cereceda, R. Espejo, R. Pinto P. Osses, and R.S. Schemenauer

2002 Fog measurements at the site "Falda Verde" North of Chañaral compared with other fog stations of Chile. Atmospheric Research 64:261-271.

Latorre, C., J.L. Betancourt, J.A. Rech, J. Quade, C. Holmgren, C. Placzek, A. Maldonado, M. Vuille, and K.A. Rylander

2005 Late Quaternary history of the Atacama Desert. In $23^{\circ} \mathrm{S}$ Archaeology and Environmental History of the Southern Deserts, edited by M. Smith and P. Hesse, pp. 73-90. National Museum of Australia Press, Canberra.

Lourandos, $\mathrm{H}$.

1993 Hunter-gatherer cultural dynamics: long- and short-term trends in Australian prehistory. Journal of Archaeological Research 1:67-88.

Mabbutt, J.A.

1971 The Australian arid zone as a prehistoric environment. In Aboriginal Man and Environment in Australia, edited by D.J. Mulvaney, and J. Golson, pp. 66-79. Australian National University Press, Canberra.

McBride, J.L., and N. Nicholls

1983 Seasonal relationships between Australian rainfall and the Southern Oscillation. Monthly Weather Review 111:1998-2004.

Middleton, N., and D. Thomas

1997 World Atlas of Desertification, Second edition. UNEP/ Arnold, London.

Moreno, A., S. Giralt, B. Valero-Garcés, A. Saéz, R. Bao, R. Prego, J.J. Pueyo, P. González-Sampériz, and C. Tabernerb

2007 A 14 kyr record of the tropical Andes: The Lago Chungará sequence ( $18^{\circ} \mathrm{S}$, Northern Chilean Altiplano). Quaternary International 161:4-21.

Moy, C.M., Seltzer, G.O., Rodbell, D.T., and D.M. Anderson 2002 Variability of El Niño/Southern Oscillation activity at millennial timescales during the Holocene epoch. Nature 420:162-165.

Mulrennan, M.E., and C.D. Woodroffe 1998 Holocene development of the lower Mary River plains, Northern Territory, Australia. The Holocene 8:565-579.
Núñez, L., and J. Varela

1967 Sobre los recursos de agua y el poblamiento prehispánico de la costa del Norte Grande de Chile. Estudios Arqueológicos Universidad de Chile 7-4:7-41.

Núñez, L., M. Grosjean, and I. Cartajena

2002 Human occupations and climate change in the puna de Atacama, Chile. Science 298:821-824.

2008 Sequential analysis of human occupation patterns and the exploitation of resources at the Atacama Desert. Chungara Revista de Antropología Chilena, accepted.

Ortlieb, L.

1995 Eventos El Niño y episodios lluviosos en el desierto de Atacama: el registro de los últimos dos siglos. Bulletin de l'Institut Français d'Études Andines 24:191-212.

Parson, M.H.

1970 Preceramic subsistence on the Peruvian coast. American Antiquity 35:292-304.

Przywolnik, K.

2005 Long-term transitions in hunter-gatherers of coastal northwestern Australia. In Desert Peoples: Archaeological Perspectives, edited by P. Veth, M. Smith, and P. Hiscock, pp. 177-205. Blackwell, Oxford.

Quinn, W.H., V.T. Neal, and S.E. Antúnez de Mayolo 1987 El Niño occurrences over the four and a half centuries. Journal of Geophysical Research 92:14449-14461.

Quinn, W.H. and V.T. Neal

1992 The historical record of El Niño events. In Climate since $A D$ 1500, edited by R.S. Bradley, and P.D. Jones, pp. 623-648. Routledge, London, New York.

Reimer, P.J., and R.W. Reimer

2001 A marine reservoir correction database and on-line interface. Radiocarbon 43:461-463.

Rein, B., Lückge, A., and F. Sirocko

2004 A major Holocene ENSO anomaly during the Medieval Period. Geophysical Research Letters 31:L17211.

Rein, B., A. Lückge, L. Reinhardt, F. Sirocko, A. Wolf, and D. Wolf-Christian

2005 El Niño variability off Peru during the last 20,000 years. Paleoceanography 20:PA4003.

Rick, J.W.

1987 Dates as data: an examination of the Peruvian preceramic radiocarbon record. American Antiquity 52:55-73.

Riedinger, M.A., M. Steinitz-Kannan, W.M. Last, and M. Brenner

$2002 \mathrm{~A} \sim 6100{ }^{14} \mathrm{C}$ yr record of El Niño activity from the Galapagos Islands. Journal of Paleolimnology 27:1-7.

Rivera, M.A.

1991 The prehistory of Northern Chile: A synthesis. Journal of World Prehistory 5:147.

Rodbell, D.T., G.O. Seltzer, D.M. Anderson, M.B. Abbott, D.B. Enfield, and J.H. Newman

1999 An 15,000-year record of El Niño-driven alluviation in Southwestern Ecuador. Science 283:516-520.

Rothhammer, F., C.M. Santoro, V.G. Standen, E. Llop, B.T. Arriaza, and M. Moraga

2008 Cultural change during Late Archaic/Formative in the Desert Valleys of Northern Chile. Link with Tropical Lowland migrations by archeological evidence and mtDNA analysis. Manuscript in possession of the author (CMS). 
Russell, T.M., editor

2004 The Spatial Analysis of Radiocarbon Databases: The Spread of the First Farmers in Europe and the Fat-tailed Sheep in Southern Africa. British Archaeological Reports, Oxford. BAR International Series 1294.

Samuel, J. M.; D.C. Verdon, M. Sivapalan, and S.W. Franks 2006 Influence of Indian Ocean sea surface temperature variability on southwest Western Australian winter rainfall. Water Resources Research 42, W08402 10.1029/2005WR004672.

Sandweiss, D.H., J.B. Richardson, E.J. Reitz, H.B. Rollins, and K.A. Maasch

1996 Geoarchaeological evidence from Peru for a 5000 Years B.P. Onset of El Niño. Science 273: 1531-1533.

Sandweiss, D.H., K.A. Maasch, R.L. Burger, J.B. Richardson, H.B. Rollins, and A. Clement

2001 Variation in Holocene El Niño frequencies: Climate records and cultural consequences in ancient Peru. Geology 29:603-606.

Seltzer, G.O., and C.A. Hastorf

1990 Climatic change and its effect on prehispanic agriculture in the central Peruvian Andes. Journal of Field Archaeology 17:397-414.

Shennan, S., and K. Edinborough

2007 Prehistoric population history: From the late glacial to the late Neolithic in Central and Northern Europe. Journal of Archaeological Science 34:1339-1345.

Shimada, I., C.B. Schaaf, L.G. Thompson, and E. MosleyThompson

1991 Cultural impacts of severe droughts in the prehistoric Andes: Application of a 1,500-year ice core precipitation record. World Archaeology 22:247-270.

Shulmeister, J.

1999 Australasian evidence for mid-Holocene climate change implies precessional control of Walker Circulation in the Pacific. Quaternary International 57/58:81-91.

Smith, M.A.

1986 Antiquity of seedgrinding in arid Australia. Archaeology in Oceania 21:29-39.

2004 The grindstone assemblage from Puritjarra rock shelter: investigating the history of seed-based economies in arid Australia. In Archaeology from Australia, edited by T. Murray, pp. 168-186. Australian Scholarly Publishing, Melbourne.

Smith, M.A., and J. Ross

2008 What happened at 1500-1000 BP in Central Australia? timing, impact, and archaeological signatures. The Holocene 18:379-388.

Smith, M.A., A. Williams, C. Turney, and M.L. Cupper 2008 Human-environment interactions in Australian drylands: exploratory time series analysis of archaeological records. The Holocene 18:389-401.

Southon, J.R., A.O. Rodman, and D. True

1995 A comparison of marine and terrestrial radiocarbon ages from Northern Chile. Radiocarbon 37:389-393.

Standen, V.G.

1997 Temprana complejidad funeraria de la cultura Chinchorro (norte de Chile). Latin American Antiquity 8:134-156.

2003 Bienes funerarios del cementerio Chinchorro Morro 1: descripción, análisis e interpretación. Chungara Revista de Antropología Chilena 35:175-207.
Standen, V., and B.T. Arriaza

2000 Trauma in the preceramic coastal populations of Northern Chile: Violence or occupational hazards? American Journal of Physical Anthropology 112: 239-249.

Standen, V., C.M. Santoro, and B.T. Arriaza

2004 Síntesis y propuestas para el período Arcaico en la costa del extremo norte de Chile. Chungara Revista de Antropología Chilena Volumen Especial: 201-212.

Sturman, A R., and N.J. Tapper

2006 The Weather and Climate of Australia and New Zealand. Second edition. Oxford University Press, Melbourne.

Thackway, R., and I.D. Cresswell

1995 An Interim Biogeographic Regionalisation for Australia: A Framework for Establishing the National System of Reserves. Australian Nature Conservation Agency, Canberra.

Tudhope, AW., C.P. Chilcott, M.T. McCulloch, E.R. Cook, J. Chappell, R.M. Ellam, D.W. Lea, J.M. Lough, and G.B. Shimmield

2001 Variability in the El Niño Southern Oscillation through a glacial interglacial cycle. Science 291:1511-1717.

Turney, C.S.M., and D. Hobbs

2006 ENSO influence on Holocene aboriginal populations in Queensland, Australia. Journal of Archaeological Science 33:1744-1748.

Ulm, S.

2006 Australian marine reservoir effects: A guide to $\Delta \mathrm{R}$ value. Australian Archaeology 63:57-60.

Usselmann, P., M. Fontugne, D. Lavallée, M. Julien, and C. Hatté

1999 Estabilidad y rupturas dinámicas en el Holoceno de la costa surperuana: el valle de la quebrada de Los Burros (Departamento de Tacna). Bulletin de l'Institut Français d'Études Andines 28:1-11.

van Buren, $M$.

2001 The archaeology of El Niño events and other "natural" disasters. Journal of Archaeological Method and Theory 8:129-149.

Verdon D.C., and S.W. Franks

2006 Long-term behaviour of ENSO: Interactions with the PDO over the past 400 years inferred from paleoclimate records. Geophysical Research Letters 33, L06712, doi:10.1029/2005GL025052.

Vermeersch, P.M.

2005 European population changes during Marine Isotope Stages 2 and 3. Quaternary International 137:77-85.

Vuille, M., R.S. Bradley, and F. Keimig

2000 Climate modes in the Central Andes and their relation to tropical Pacific and Atlantic forcing. Journal of Geophysical Research 105:12447-12460.

Weedon, G.

2003 Time-Series Analysis and Cyclostratigraphy: Examining Stratigraphic Records of Environmental Cycles. Cambridge University Press, Cambridge.

Williams, A.N., M.A. Smith, C.S.M. Turney, and M.L. Cupper

2007 AustArch1: A database of ${ }^{14} \mathrm{C}$ and luminescence ages from archaeological sites in the Australian arid zone. http:// palaeoworks.anu.edu.au/databases.html.

Woodroffe, C.D., B.G. Thom, and J. Chappell

1985 Development of widespread mangrove swamps in mid-Holocene times in Northern Australia. Nature 317:711-13. 
